\title{
Peningkatan Kualitas Kompetensi Guru PAUD: Menjadi Guru Profesional
}

\author{
Wahyuni Nadar ${ }^{1 *}$, Yatha Yuni $^{2}$, Lutfi Hardiyanto ${ }^{3}$ \\ ${ }^{1}$ Pendidikan Guru PAUD, STKIP Kusuma Negara \\ ${ }^{2}$ Pendidikan Matematika, STKIP Kusuma Negara \\ ${ }^{3}$ Pendidkan Pancasila dan Kewarganegaraan, STKIP Kusuma Negara \\ *nadar@stkipkusumanegara.ac.id
}

\begin{abstract}
Abstrak
Kompetensi profesional merupakan satu kompetensi pendidik yang harus dimiliki guru PAUD. Menyusun perencanaan pembelajaran merupakan bagian dari kompetensi profesional. Perencanaan pembelajaran dimulai dari program semester, rencana perencanaan pembelajaran mingguan (RPPM) dan rencana perencanaan pembelajaran harian (RPPH). Rencana Pelaksanaan Pembelajaran merupakan salah satu hal penting yang harus diperhatikan oleh tenaga pendidik khususnya pada pendidik anak usia dini. Dalam memberikan sebuah kegiatan pembelajaran yang baik kepada para peserta didik, harus dibuat RPPH. RPPH ini memiliki berbagai macam peran penting dalam sebuah kegiatan pembelajaran, diantaranya dapat mempermudah pelaksanaan kegiatan pembelajaran karena di dalam RPPH terdapat tujuan, metode, dan media yang akan digunakan ketika kegiatan belajar berlangsung. Selain itu, RPPH juga dapat menjadi sebuah acuan dalam evaluasi pembelajaran agar pendidik mampu terus berinovasi dalam menciptakan kegiatan pembelajaran yang bermakna bagi peserta didik. Pada kegiatan pengabdian masyarakat $(\mathrm{PkM})$ berupa pelatihan diikuti oleh guru-guru PAUD di Desa Ciadeg Cigombong. Kegiatan ini dilaksanakan selama dua hari. Adapun tim dosen yang melaksanakan kegiatan PkM berjumlah 8 orang yang kesemuanya merupakan dosen lintas prodi di STKIP Kusuma Negara. Hasil pelatihan menunjukan adanya peningkatan pemahaman dan keterampilan peserta latihan melalui pretes dan postes secara lisan, dan dilihat dari hasil evaluasi membuat perangkat administrasi pembelajaran meliputi program semester, RPPM, dan RPPH.
\end{abstract}

Kata kunci: kompetensi guru PAUD, perencanaan pembelajaran, profesional.

Dikirim: 10 April 2021

Direvisi: 26 April 2021

Diterima: 28 April 2021

\section{PENDAHULUAN}

Pendidikan Anak Usia Dini (PAUD) merupakan program prioritas pertama dan utama dalam fokus pembangunan pendidikan di Indonesia tahun 2010-2014 (Kemendiknas, 2011). Keberhasilan PAUD tidak terlepas dari peran pendidik PAUD mengingat peran utamanya dalam mengasuh, merawat, mendidik dan melindungi dalam upaya memaksimalkan seluruh sel otak yang saat lahir sudah terbentuk. Sebagai pendidik PAUD yang profesional, mereka bertugas untuk merencanakan, melaksanakan proses pembelajaran, dan menilai hasil pembelajaran, serta melakukan pembimbingan, pengasuhan, dan perlindungan kepada anak didik.

Pendidikan anak usia dini bertujuan untuk membentuk anak yang berkualitas, anak yang tumbuh dan berkembang sesuai dengan tingkat perkembangannya. Pendidikan anak usia dini merupakan pendidikan yang mendasar dan strategis dalam pembangunan sumber daya manusia yang unggul dan berkualitas (Nadar, 
2019). Oleh sebab itu pendidik anak usia dini haruslah guru yang kompeten dan profesional pada bidang PAUD, karena pendidikan pada anak usia dini adalah awal pembentukan yang menentukan karakter mereka kelak.

Kenyataan yang ada di lapangan, banyak pendidik PAUD yang belum memenuhi kualifikasi bahkan kompetensinya di bidang "mendidik anak usia dini". Masih banyak pendidik PAUD yang memiliki tingkat pendidikan hanya sekolah menengah atas atau yang sederajat (SMA atau SMK) namun ikut berpartisipasi mengajar di tingkat RW yang dikelola oleh ibu-ibu PKK. Temuan dilapangan, masih sedikit yang berpendidikan diploma dan sarjana, dan tidak relevan/sesuai dengan bidang pendidikan anak usia dini. Bahkan tidak jarang pendidik PAUD yang berasal dari ibu-ibu PKK (Program Kesejahteraan Keluarga) di sekitar lingkungannya. Layanan-layanan PAUD sebagian besar dilakukan oleh tenaga pendidik dengan kualifikasi pendidikan yang bervariasi. Di lihat dari latar belakang pendidikan masih banyak tenaga pendidik anak usia dini (PAUD non formal yang berlatar belakang SMA ke bawah), sementara Peraturan Pemerintah No.19 Tahun 2005 mempersyaratkan bahwa "Pendidik pada pendidikan anak usia dini memiliki kualifikasi akademik pendidikan minimum diploma empat atau sarjana" (Nurhayati \& Rakhman, 2017). Hal ini juga dialami oleh PAUD yang ada di desa Ciagel Cigombong, disebabkan selain kekurangan tenaga pendidik PAUD yang kompeten, juga disebabkan kepedulian ibu-ibu PKK yang sangat besar terhadap masa depan anak.

Masalah kekurangan tenaga pendidik PAUD juga terjadi di Kelurahan Cigombong, Kecamatan Ciadeg, Kabupaten Bogor. Dari hasil observasi awal berdasarkan laporan alumni PAUD yang pernah melaksanakan PPL di kelurahan Cigombong, ada beberapa lembaga PAUD yang tenaga pendidiknya masih belum mampu menyusun rencana pembelajaran dengan baik dan benar di desa Ciadeg, padahal RPP merupakan hal penting yang harus dipahami dan dikuasai oleh pendidik khususnya pendidik anak usia dini. Selain itu mereka kurang memahami karakteristik perkembangan anak dan proses pembelajaran yang mereka lakukan belum sesuai dengan Permendiknas No. 58 tahun 2009. Kurangnya pengetahuan mereka terhadap perkembangan anak membuat suasana belajar terkesan sangat monoton dengan kegiatan yang juga kurang sesuai dengan kebutuhan anak usia dini. Berdampak pembelajaran yang diterima anak kurang membangun kreativitas dan kurang membangun tumbuh kembang perilaku anak. Pembelajaran kurang inovatif dan suasana belajar terlihat kurang menarik bagi anak-anak. Lebih terkesan guru memberikan kebebasan yang kurang terarah, pada saat belajar menulis seperti tampak pada Gambar 1.
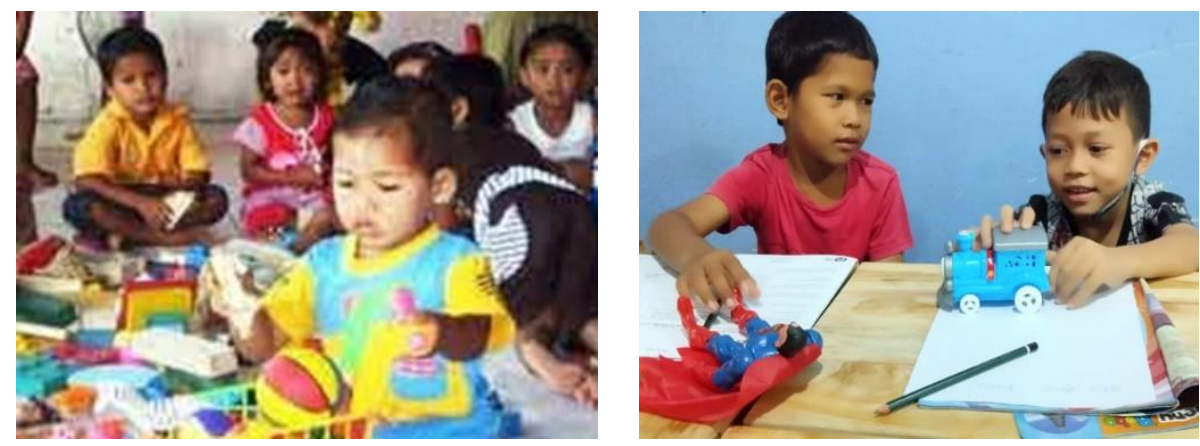

Gambar 1. Suasana belajar anak-anak pada dua PAUD di Desa Ciadeg yang belum terarah 
Hal inilah yang menjadi ketertarikan tim prodi PAUD STKIP Kusuma Negara untuk melakukan pengabdian masyarakat dengan memberikan pelatihan membuat perangkat administrasi pembelajaran di desa Ciadeg. Tujuan melaksanakan pelatihan ini agar guru-guru PAUD di desa tersebut menjadi lebih bertambah pengetahuan, pengalaman dan keterampilannya dalam perencanaan, melaksanakan proses pembelajaran dan evaluasi hasil pembelajaran.

\section{Kompetensi Guru PAUD}

Pemaparan tentang kompetensi guru PAUD tertera dengan jelas dalam Undangundang guru dan dosen no. 14 tahun 2005 pasal 2. Sanjaya (2009:4) menjelaskan tentang undang-undang tersebut bahwa guru memiliki kedudukan sebagai tenaga profesional pada jenjang pendidikan dasar, pendidikan menengah dan pendidikan anak usia dini pada jalur pendidikan formal. Selanjutnya pada pasal 4, dijelaskan bahwa guru sebagai tenaga profesional sebagaimana dimaksudkan dalam pasal 2, berfungsi meningkatkan martabat dan peran guru, sebagai agen pembelajaran, dan berfungsi untuk meningkatkan mutu pendidikan nasional. Adapun kompetensi guru merupakan kemampuan dan kewenangan guru dalam menjalankan kewajiban-kewajibannya dengan penuh tanggung jawab akan tugasnya sebagai guru. Karena guru merupakan suatu profesi atau pekerjaan yang bersifat soft skill, maka kompetensi sangat dibutuhkan dalam proses belajar mengajar (Alkornia, 2016). Soft skill harus dilatih dan dipraktekan, tidak cukup hanya mempelajari teori saja. Inilah yang mendasari pelaksanaan pelatihan oleh tim dosen STKIP Kusuma Negara kepada guru-guru PAUD di desa Ciadeg kabupaten Bogor.

Peningkatan mutu pendidikan di Indonesia digambarkan dengan adanya kompetensi yang harus dimiliki oleh guru yaitu kompetensi profesional, pedagogis, kepribadian, dan sosial, sebagaimana tercantum dalam Peraturan Pemerintah No. 16 tahun 2007 tentang standar kompetensi guru PAUD/TK/RA. Berikut dijabarkan masing-masing kompetensi tersebut antara lain yaitu: (1) Kompetensi kepribadian adalah kemampuan untuk bersikap dan berperilaku sesuai dengan kebutuhan psikologis anak, sesuai dengan norma, agama, budaya dan keyakinan anak, dan menampilkan diri sebagai pribadi yang berbudi pekerti luhur. (2) Kompetensi profesional terkait dengan kemampuan untuk memahami tahapan perkembangan anak, pertumbuhan dan perkembangan anak, kemampuan untuk memberikan rangsangan pendidikan, pengasuhan danperlindungan, dan kemampuan untuk membangun kerjasama dengan orang tua dalam pendidikan, pengasuhan dan perlindungan anak. (3) Kompetensi pedagogik adalah kemampuan yang terkait dengan merencanakan kegiatan program pendidikan, pengasuhan dan perlindungan, melaksanakan proses dan melaksanakan penilaian terhadap proses dan hasil pendidikan, pengasuhan, dan perlindungan. Sedangkan Kompetensi sosial adalah kemampuan guru dalam beradaptasi dengan lingkungan dan berkomunikasi secara efektif dengan anak didik, dan orang tua.

Menjadi guru profesional bukan hal mudah. Istilah profesional mengacu pada dua hal. Pertama orang yang menyandang suatu profesi. Kedua, kinerja atau performance seseorang dalam melakukan pekerjaan yang sesuai dengan profesinya. Pengembangan kompetensi professional yang diaplikasikan dalam membuat perencanaan pembelajaran menjadi bagian yang dituntut dalam pembelajaran di PAUD. Suhana (2014: 166) memaparkan dengan menguasai materi pembelajaran, guru dapat memilih, menetapkan dan mengembangkan 
alternatif strategi dari berbagai sumber belajar yang mendukung pembentukan standar kompetensi dan kompetensi dasar. Guru harus memiliki kemampuan mendisain perencanaan pembelajaran sesuai tema, tahapan perkembangan dan tujuan pembelajaran yang menyenangkan, bermakna dan mengeksplor rasa ingin tahu anak. Sebagaimana yang dikatakan oleh Semiawan (2002: 25), guru membutuhkan pengetahuan dan keterampilan agar dapat membimbing anak-anak untuk tumbuh dan berkembang dengan baik.

\section{METODE PELAKSANAAN}

Pelaksanaan kegiatan pengabdian masyarakat ini dilakukan dengan melakukan pelatihan selama dua hari, tepatnya hari Selasa dan Rabu tanggal 3 dan 4 September 2019 dari jam 08.00-16.00. Peserta pelatihan adalah guru-guru PAUD sebanyak 25 orang yang mengajar di 12 PAUD yang berbeda di Desa Ciadeg Kelurahan Cigombong Kabupaten Bogor Jawa Barat. Apabila dilihat pada peta Indonesia lokasi Desa Ciadeg yang sejuk sebagai berikut:

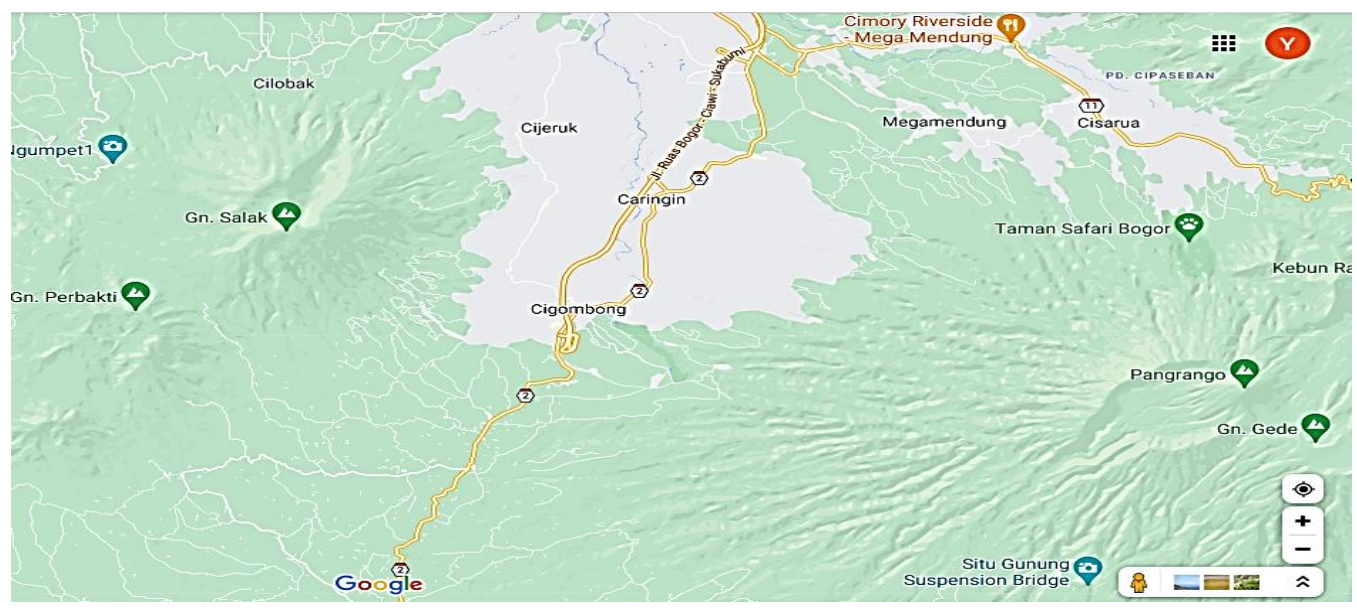

Gambar 1. Peta lokasi Tempat Pengabdian di desa Ciadeg Kelurahan Cigombong

Pelaksana pengabdian kepada masyarakat ini dilakukan oleh 8 dosen, 5 dosen sebagai narasumber, dan seluruh dosen menjadi tutor dihari kedua. Kegiatan PkM dengan pelatihan ini melibatkan 5 mahasiswa PAUD, dan seorang alumni.

Hari pertama workshop, para peserta diberikan materi oleh 5 narasumber tentang: (1) Kompetensi Guru PAUD; (2) Perencanaan Pembelajaran PAUD meliputi Program semester, RPPM dan RPPH. Sebelum diberikan materi dihari pertama pelatihan, peserta diberikan pretest berupa tes lisan yang ditanya ke semua peserta pelatihan secara bergantian. Hal ini dilakukan utnuk mengetahui perubahan sebelum dan sesudah pelatihan.

Materi hari kedua pelatihan memberikan bimbingan mengimplementasikan teori yang telah diberikan pada hari pertama dengan praktik membuat program semester, RPPM dan RPPS. Kegiatan praktik didampingi oleh dosen-dosen yang menjadi narasumber dan mahasiswa. Guru-guru PAUD di Kelurahan Cigombong sebagai peserta pelatihan membuat program semester, RPPM, dan RPPH, dilakukan secara berkelompok, setiap tiga guru PAUD didampingi oleh satu dosen dan satu mahasiswa dari STKIP Kusuma Negara. Tujuan dibentuk kelompok agar dapat saling berbagi melalui diskusi kelompok. 
Dosen pendamping yang berperan sebagai tutor, melakukan pembimbingan praktik dengan teknik demonstrasi, Tanya-jawab dan diskusi. Guru yang mengalami kesulitan menanyakan kepada tutornya, diberi arahan didiskusikan dengan anggota dalam kelompok, sambil menceritakan pengalaman saat mereka mengajar. Kesulitan-kesulitan ataupun hal-hal yang pernah dilakukan mereka saat proses KBM dikelas PAUD itulah yang didiskusikan, lalu dicarikan solusinya dan dituliskan dalam RPPM dan RPPH.

\section{HASIL DAN PEMBAHASAN}

Berdasarkan hasil prestest diawal kegiatan pelatihan, 19 orang yang berasal dari 12 PAUD yang berbeda menyatakan belum membuat program semester sendiri. Sekalipun mereka pernah mendapatkan pelatihan membuat program semester dari organisasi profesi yang ada di Kecamatan Ciadeg. Namun masih belum mampu membuat adminitrasi pembelajaran. Ketika ditanyakan alasannya, mereka menjawab pada saat pelatihan belum melakukan praktik yang dibimbing pakar. 6 peserta yang berasal dari 4 lembaga PAUD sudah meyusun sendiri program semesternya, namun mereka belum yakin yang dibuat sudah layak digunakan atau diimplementasikan. Suasana pretes sebelum materi disampaikan narasumber pertama.

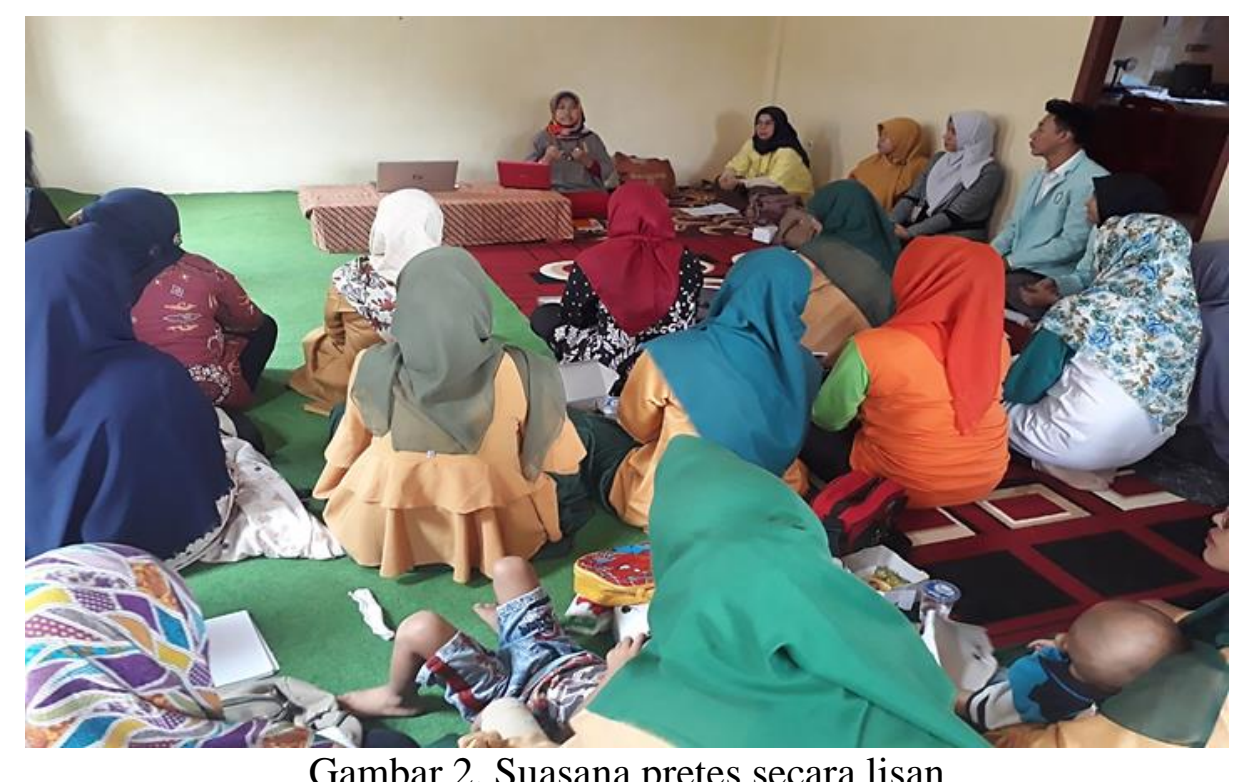

Gambar 2. Suasana pretes secara lisan

Berdasarkan hasil evaluasi tutor yang merupakan postes, semua peserta pelatihan dalam membuat RPPM baik pada disain perencanaan pembelajaran di RPPM belum terlihat kegiatan yang bermakna (parsial) dan belum terintegrasi dengan baik antara tema dan kegiatan. Bentuk RPPH di masing-masing lembaga PAUD berbeda-beda, yang sebenarnya tidak dipermasalahkan selama isi RPPH menggambarkan disain pembelajaran yang jelas dan runtut. Ketika praktik dilakukan, semua peserta diberikan referensi dan contoh bentuk RPPM dan RPPH yang mudah, efekstif dan efisien. Setelah pelatihan peserta sudah memiliki pemahaman yang meningkat, hal ini terlihat dari hasil penyusunan RPPM dan RPPH yang lebih kreatif dan inovatif dalam pemilihan permainan, media, dan 
metode pembelajaran dengan memanfaatkan media yang mereka miliki. Kegiatan dalam RPPH lebih runtut dan terbaca jelas, kegiatan yang dilakukan lebih bermakna dalam membangun pengetahuan, keterampilan, dan perkembangan motorik anak.

Pada pelatihan ini, peserta pelatihan diperagakan cara membuat media pembelajaran dengan material yang ada disekitar dan terjangkau namun menarik dan dengan media tersebut membuat anak lebih senang untuk belajar. Ada juga narasumber yang mengajarkan mencari media pembelajaran melalui gadget (HP). Suasana pelatihan saat memanfaatkan gadget atau HP terlihat sebagai berikut:

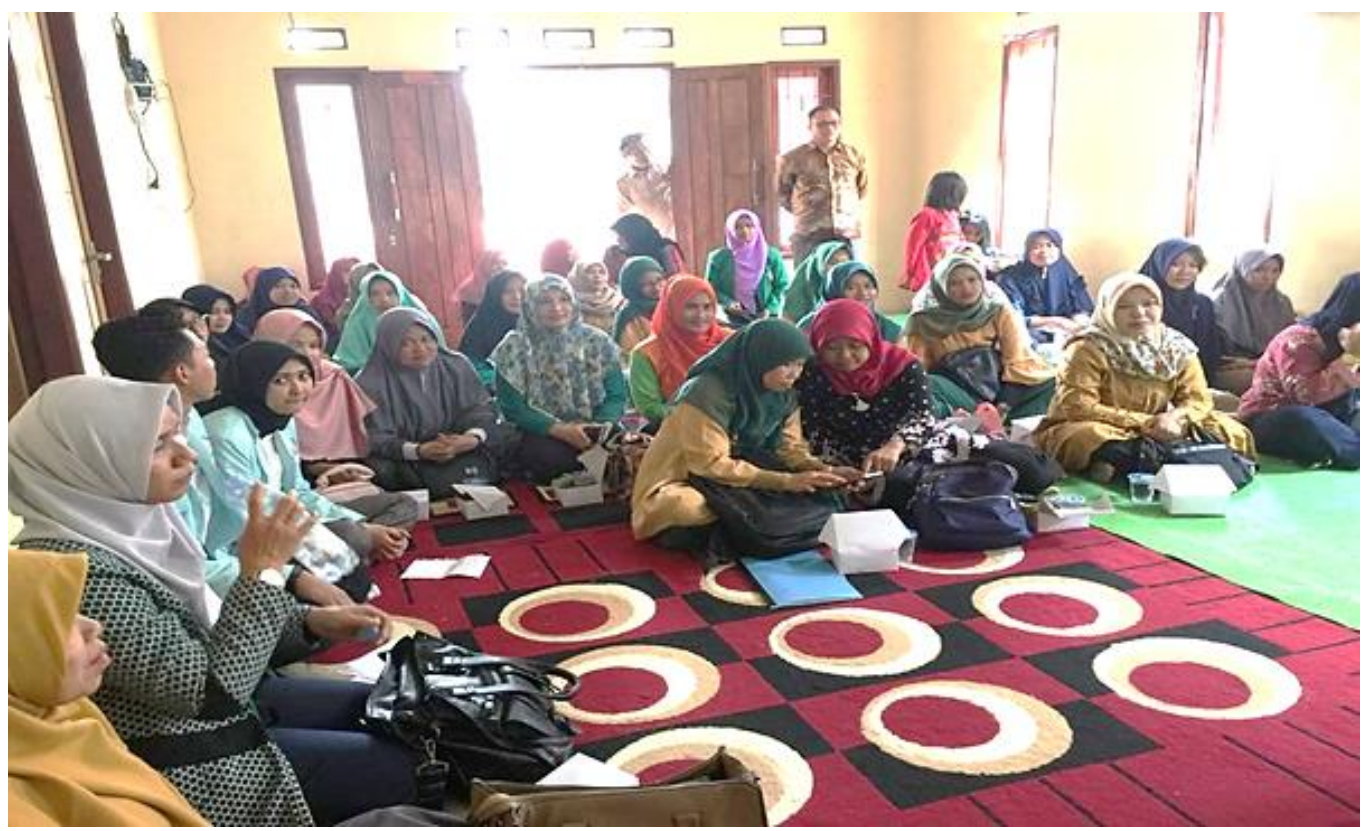

Gambar 3. Suasana praktik diakhir hari kedua memanfaatkan Gadget (HP)

Dua hari bersama dengan guru-guru PAUD di desa Ciadeg, Cigombong sangat lah menyenangkan, karena semangat dan antusia mereka yang luar biasa. Tidak sedikitpun terlihat rasa lelah sekalipun pelatihan dilakukan dari jam 08.00 sampai jam. 16.00. Pada saat praktik di hari kedua suasana pelatihan lebih meriah dan menggembirakan dengan bernyanyi, bertepuk tangan, canda dan tertawa. Mahasiswa PAUD dan alumni mengajarkan lagu-lagu anak yang baru dan dapat dipraktikan pada saat mereka mengajar nanti. Terlihat pada Gambar 3 pak Lurah Cigombong hadir memantau pelatihan para guru-guru PAUD sambil berdiri dibelakang para peserta. Ketua Tim PkM sempat mewawancara Bapak Lurah untuk menanyakan pendapat beliau tentang pelatihan yang dilakukan. Beliau terharu, puas dan senang dengan perhatian dosen-dosen STKIP Kusuma Negara. Bahkan beliau berharap kami akan datang lagi dengan melakukan pelatihan lainnya. Saat itu ketua tim mengatakan insya Allah kami akan datang di awal tahun 2020 untuk melakukan observasi lanjutan akan kemajuan keterampilan guru-guru PAUD yang kami latih. Namun sayang, pandemi covid-19 menghalangi niat kami, observasi hanya bisa kami lakukan dengan menelpon alumni yang manjadi informan untuk menanyakan kemajuan dan perkembangan guru-guru PAUD desa Ciadeg. Alumni mengatakan sudah banyak kemajuan terjadi di beberapa PAUD, perangkat pembelajaran telah mereka buat dan 
praktikan, manfaatnya pun langsung dirasakan. Suasana belajar lebih terarah, tidak hanya sekedar tempat bermain saja, tetapi bermain sambil belajar dengan suasana yang menggembirakan, menyenangkan. Bahkan para guru sudah lebih kreatif dengan menciptakan lagu-lagu anak yang baru.

Pada akhir pertemuan dihari kedua, kami sempatkan berfoto bersama sebagai bukti laporan PkM dan tentunya menjadi kenang-kenangan bagi kami semua.

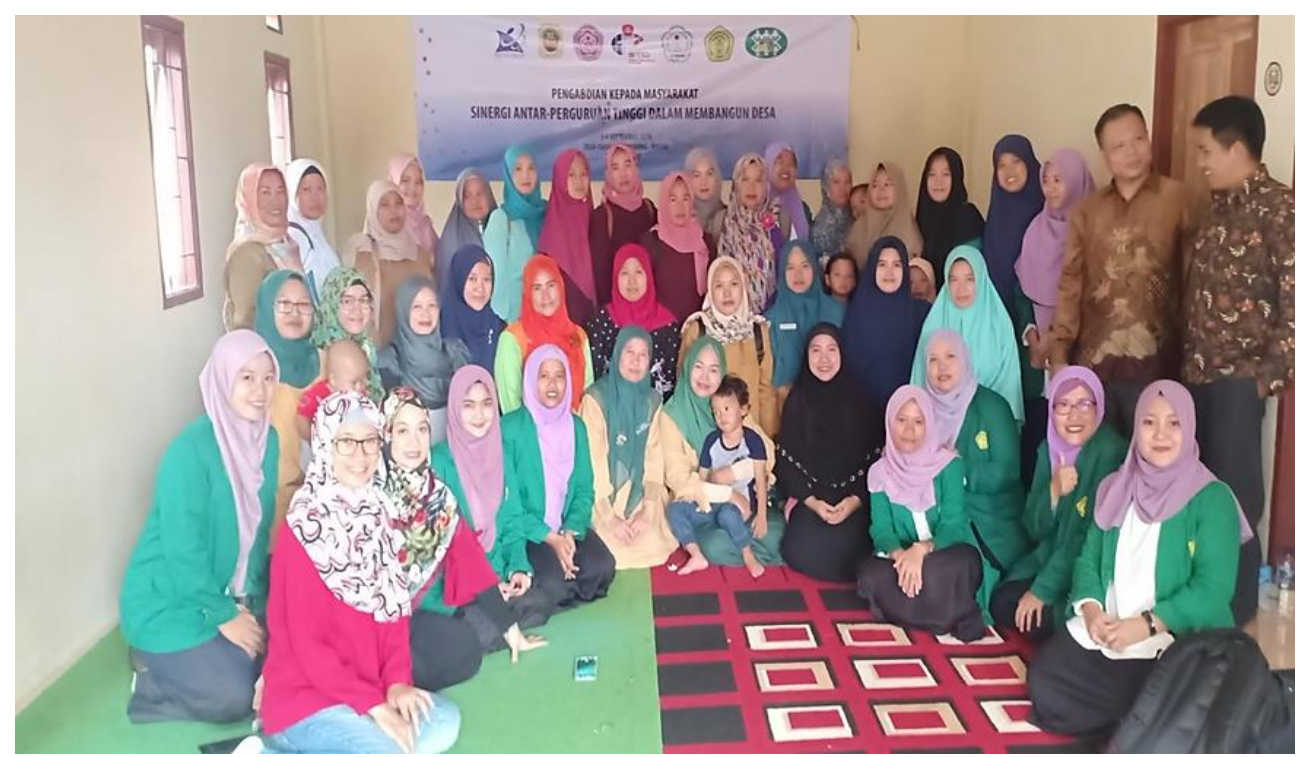

Gambar 4. Foto bersama setelah selesai pelatihan dihari kedua

\section{SIMPULAN}

Guru-guru PAUD di Desa Ciadeg Kelurahan Cigombong masih memiliki pengetahuan dan keterampilan yang masih minim dalam penyusunan perencanaan pembelajaran, padahal pnyusunan perencanaan pembelajaran merupakan salah satu indicator yang ada dalam kompetensi professional. Oleh karena itu, dibutuhkan program penguatan kompetensi guru-guru PAUD untuk semua kompetensi secara berkala dan berkelanjutan dari dinas pendidikan setempat dan juga organisasi profesi terkait. Dengan adanya kegiatan Pengabdian kepada Masyarakat (PkM) yang telah dilaksnakan oleh STKIP Kusuma Negara bekerja sama dengan Desa Ciadeg Kelurahan Cigombong dapat meningkatkan kompetensi professional guru-guru PAUD dalam menyusun perencanaan pembelajaran.

\section{UCAPAN TERIMA KASIH}

Ucapan terima kasih kami haturkan untuk Kepala Desa Ciadeg, Ketua STKIP Kusuma Negara, Ketua HIMPAUDI Kelurahan Cigombong, Peserta workshop yang terdiri dari guru-guru PAUD di Kelurahan Cigombong, Dosen- dosen STKIP Kusuma Negara, mahasiswa PAUD STKIP Kusuma Negara, dan semua pihak yang telah membantu terlaksananya kegiatan ini. Semoga semua bantuan yang telah diberikan mendapat pahala dari Allah SWT. 


\section{DAFTAR PUSTAKA}

Alkornia, S. (2016). Studi Deskriptif Kompetensi Pedagogik dan Profesionalisme Guru PAUD Dharma Wanita Binaan SKB Situbondo. Skripsi, tidak dipublikasikan. Jember: Repository UNEJ.

Kementrian Pendidikan Nasional. (2011). Pendidikan Anak Usia Dini, Jakarta: Kemendiknas.

Nadar, W. (2019). Peningkatan kedisiplinan anak usia dini melalui metode pembiasaan token economy. ElementerIs: Jurnal Ilmiah Pendidikan Dasar Islam, 1(1), 1-11.

Nurhayati, S., \& Rakhman, A. (2017). Studi kompetensi guru PAUD dalam melakukan asesmen pembelajaran dan perkembangan anak usia dini di kota Cimahi. Jurnal Pendidikan Anak, 6(2), 109-120.

Sanjaya, W. (2009). Strategi Pembelajaran Berorientasi Standar Proses Pendidikan. Jakarta: Kencana Prenada Media Group.

Semiawan, C. R. (2002). Belajar dan Pembelajaran dalam Taraf Usia Dini. Jakarta: PT. Ikrar Mandiri Abadi.

Suhana, C. (2014). Konsep Strategi Pembelajaran (Cetakan ke-4). Bandung: Refika Aditama. 